\title{
Perkembangan koperasi di Jawa Timur
}

\section{Cooperative development in East Java}

\author{
Tuti Budirahayu \\ Departemen Sosiologi, Fakultas Ilmu Sosial dan Ilmu Politik, Universitas Airlangga \\ E-mail: tuti.budirahayu@fisip.unair.ac.id
}

\begin{abstract}
Abstrak
Koperasi adalah lembaga sosial-ekonomi yang memiliki peran penting dalam mendukung perkembangan kegiatan ekonomi kerakyatan, penanganan kemiskinan dan pengangguran di Provinsi Jawa Timur, tetapi hingga kini data base perkembangan koperasi di Jawa Timur belum tertata dengan baik. Ditengarai hingga saat ini masih banyak koperasi yang belum terdata dengan akurat, dan kalau pun tersedia data perkembangan koperasi umumnya masih belum banyak dimanfaatkan sebagai acuan dalam penyusunan program pembinaan dan pemberdayaan koperasi yang benar-benar kontekstual. Tujuan keiatan ini adalah, Pertama, untuk mengetahui pasang-surut perkembangan koperasi di Jawa Timur. Kedua, untuk memetakan problema dan berbaga kendala yang dihadapi koperasi dalam upaya mengembangkan kegiatan usaha dan melayani anggotanya. Ketiga, untuk dasar merumuskan program yang benar-benar efektif dalam upaya pemberdayaan koperasi di Jawa Timur. Metode yang digunakan pertama, melakukan pengumpulan data. Kedua, melakukan analisis data sekunder Ketiga, melakukan kajian lapangan, yakni langsung mewawancarai para anggota dan pengurus Koperasi di Jawa Timur. Hasil dari penelitian ini anggota koperasi mengalami peningkatan juga dari kebutuhan simpan pinjamnya. Prospek kedepan, perkembangan koperasi diyakini sebagian besar responden akan makin besar, sebab banyak warga masyarakat yang membutuhkan koperasi untuk tempat meminjam modal usaha mau pun untuk memenuhi kebutuhan hidup sehari-hari.
\end{abstract}

Kata kunci: lembaga; simpan pinjam; perkembangan; anggota; masyarakat

\begin{abstract}
Cooperative is a socio-economic institution that has an important role in supporting the development of social economic activities, handling poverty and unemployment in East Java Province, but until now the database of cooperative development in East Java has not been well-organized. It is suspected that up to now there are still many cooperatives that have not been accurately recorded, and even if available data on the development of cooperatives are generally not widely used as a reference in the preparation of co-operative development and empowerment programs that are truly contextual. The purpose of this activity is, First, to find out the ups and downs of the development of cooperatives in East Java. Second, to map the problems and various constraints faced by cooperatives in developing business activities and serving their members. Third, to formulate a truly effective program in the effort to empower cooperatives in East Java. The method used first is to collect data. Second, conducting secondary data analysis Third, conducting field studies, namely directly interviewing members and administrators of the Cooperative in East Java. The results of this study cooperative members also increased from the needs of savings and loans. Prospects for the future, the development of cooperatives is believed by most of the respondents to be even greater, because there are many citizens who need cooperatives to borrow business capital to meet their daily needs.
\end{abstract}

Keywords: institutions; savings and loans; development; members; community

\section{Pendahuluan}

Koperasi berasal dari kata "co" yang artinya bersama serta "operation” yang bermakna bekerja. Jadi, secara leksikologis koperasi adalah sebagai suatu kumpulan kerja sama yang beranggotakan beberapa atau badan hukum yang memberikan kebebasan keluar dan masuk sebagai anggota koperasi dimana kegiatannya berdasarkan kepada prinsip koperasi dan juga sebagai gerakan ekonomi rakyat yang berlandaskan atas azas kekeluargaan (Anoraga, 2002). Landasan Koperasi ialah Pancasila dan UUD 1945, berlandaskan asas kekeluargaan dengan tujuan meningkatkan kesejahteraan anggota dan mengutamakan kebutuhan masyarakat, sekaligus sebagai bagian dari sistem perekonomian nasional yang demokratis dan berkeadilan (Agustia \& Palupi, 2016). 
Nilai-nilai dasar koperasi antara lain kekeluargaan, tanggung jawab, demokrasi, egaliter, adil, dan mandiri, dengan keyakinan nilai anggotanya yang jujur, terbuka, tanggung jawab,dan peduli terhadap orang lain, dimana prinsip koperasi yang menjadi sumber inspirasi yang menjiwai keseluruhan organisasi dan sesuai dengan maksud dan tujuan pendiriannya, itulah ciri khas yang membedakan koperasi dengan badan usaha lain (Warno \& Setiyanti, 2014).

Meski telah disadari bahwa koperasi adalah lembaga sosial-ekonomi yang memiliki peran penting dalam mendukung perkembangan kegiatan ekonomi kerakyatan, penanganan kemiskinan dan pengangguran di Provinsi Jawa Timur, tetapi hingga kini data base perkembangan koperasi di Jawa Timur belum tertata dengan baik. Ditengarai hingga saat ini masih banyak koperasi yang belum terdata dengan akurat, dan kalau pun tersedia data perkembangan koperasi umumnya masih belum banyak dimanfaatkan sebagai acuan dalam penyusunan program pembinaan dan pemberdayaan koperasi yang benar-benar kontekstual.

Sehubungan dengan tugas dan peranan koperasi dalam rangka pembangunan nasional dan peningkatan ekonomi, hal yang utama harus terlaksana dengan efektif yakni terkait penanganan dan pengelolaan koperasi agar dapat berfungsi dengan sebaik-baiknya sehingga perkembangan koperasi dapat terwujud terlihat dari meningkatnya kualitas dan kualitas koperasi yang ada (Sulindawati, 2012).

Penelitian ini merujuk pada Melani dkk (2013) yang meneliti KSU Citra Nelayan, koperasi memiliki peran membantu anggota dalam menampung hasil tangkapan dan kemudian baru dipasarkan serta masih rendahnya SDM anggota serta hasil tangkapan yang masih rendah sehingga tidak dapat memenuhi permintaan pasar. Peran Koperasi Dalam Pengembangan Perekonomian Rakyat, di mana hasilnya menjelaskan bahwa pendekatan pengembangan koperasi yang harus dilakukan adalah pendekatan pengembangan kelembagaan secara partisipatif dan menghindari pengembangan yang berdasarkan pada kepatuhan atas arahan dan lembaga lain, masyarakat perlu ditumbuhkan kesadarannya untuk mampu mengambil keputusan sendiri demi kepentingan sendiri (Heriyono, 2012; Ilhamidya, 2020; Syamsuri, 2020; Yuniarta, 2020). Studi tentang pengembangan koperasi jeruk pamelo di Magetan menggunakan Strategi SO (Aggressive Strategies) yang merupakan strategi bernuansa pengembangan atau ekspansif atau bisa juga disebut dengan strategi pendekatan fokus, yakni pendekatan yang sesuai dengan permasalahan spesifik yang dihadapi para petani, dengan mempertimbangkan kondisi relatif terbatasnya kualitas sumberdaya manusia dan sumbedaya lain yang dimiliki koperasi (Arifandy, 2018).

Yang dimaksud data base koperasi di sini tentu bukan sekadar catatan tentang jumlah dan jenis koperasi. Tetapi, yang terpenting adalah bagaimana data yang ada kemudian ditindaklanjuti sebagai acuan dalam menyusun program pemberdayaan dan pengembangan koperasi yang tepat. Bagi masyarakat dan pemerintah, kita tahu bahwa yang namanya koperasi adalah salah satu penyumbang pertumbuhan perekonomian terbesar di Jawa-Timur, dan mampu memperkuat perekonomian bangsa. Selain itu koperasi dan (juga UMKM) juga merupakan pelaku ekonomi yang memiliki peran yang sangat penting dan strategis dalam membangun perekonomian rakyat. Di tahun 2012, misalnya Koperasi dan UMKM memberikan nilai konstribusi sebesar 57\% dari Produk Domistik Regional Bruto (PDRB) Jawa-Timur sebesar Rp 884 trilyun, sehingga yang berhasil di sumbangkan dari Koperasi dan UMKM sebesar 600 trilyun. Sesuai dengan data yang diperoleh dari BPS 2012 jumlah Koperasi di Jawa Timur tercatat sebesar 29.267 unit, sedangkan untuk UMKM di Jawa Timur jumlah nya mencapai 6,8 juta, dan dari Jumlah UMKM tersebut 5,78 juta atau 85\% adalah Usaha Mikro.

Kontribusi sektor perkoperasian di Jawa Timur terhadap pertumbuhan perkoperasian secara nasional tercatat mencapai 32\%. Dibanding perkoperasian dari provinsi lain yang hanya rata-rata $15 \%$, perkoperasian di Jawa Timur memegang peranan utama terhadap pertumbuhan koperasi secara nasional. Dari sekian banyak provinsi lain di Indonesia, Jawa Timur merupakan satu-satunya provinsi yang sektor perkoperasian dan UMKM-nya memiliki peran penting dalam memajukan perekonomian daerah. Dari sejumlah penilaian, sektor koperasi di Jawa Timur merupakan peringkat satu dan 
memiliki peran utama dalam mendukung ekonomi kerakyatan jika dibanding 33 provinsi lainnya. Menurut data Dinas Koperasi dan UMKM Jatim, di Jawa Timur dari 24.000 lebih koperasi yang ada di tahun 2011, tumbuh menjadi sekitar 29.263 koperasi. Sedangkan untuk aset tercatat mencapai sekitar Rp 24 triliun. Sementara jumlah anggota naik 34,8\% dari 5.209.364 menjadi 7.021.337 orang. Dengan volume pinjaman mencapai Rp 26,2 triliun pada 2011. Setahun sebelumnya sebesar Rp11,4 triliun atau naik 17,6\%. Total aset naik dari Rp14,5 triliun menjadi Rp 20 triliun.

Sebagai provinsi terbesar nomor dua di Indonesia, Jawa Timur selama ini telah berhasil membuktikan menjadi provinsi lokomotif bagi gerakan koperasi di Indonesia. Di tahun 2013, alokasi dana yang digelontorkan Pemerintah Provinsi Jawa Timur untuk pemberdayaan koperasi dan UMKM sekitar Rp 1,3 triliun. Sebagai wujud komitmen Pemerintah Provinsi Jawa Timur untuk mendorong pengembangan koperasi, di tahun 2013 tercatat ada sekitar 80 koperasi karyawan yang telah memperoleh bantuan hibah modal, yakni masing-masing koperasi sebesar Rp. 25.000 .000 (dua puluh lima juta rupiah). Bantuan modal ini digulirkan dengan tujuan agar karyawan yang ada di berbagai perusahaan memiliki kesempatan untuk mengembangkan usaha dan/atau untuk membantu mereka jika membutuhkan dana ekstra --entah untuk kebutuhan pendidikan anak, kesehatan, atau untuk memenuhi kebutuhan hidup sehari-hari. Selain itu, pemerintah Provinsi Jawa Timur juga telah mengucurkan bantuan untuk mendukung pengembangan koperasi pondok pesantren, koperasi wanita, dan lain-lain.

Untuk mengetahui sejauhmana berbagai program pemberdayaan koperasi yang telah dilakukan Pemerintah Provinsi Jawa Timur terbukti memberikan manfaat, dan sekaligus untuk mengidentifikasi berbagai kendala yang menghambat upaya pengembangan koperasi di Provinsi Jawa Timur, karena itu perlu dilakukan kegiatan penyusunan data base perkembangan koperasi di Jawa Timur. Arti penting kegiatan penyusunan data base koperasi di Jawa Timur ini adalah: Pertama, untuk mengetahui pasangsurut perkembangan koperasi di Jawa Timur. Kedua, untuk memetakan problema dan berbaga kendala yang dihadapi koperasi dalam upaya mengembangkan kegiatan usaha dan melayani anggotanya. Ketiga, untuk dasar merumuskan program yang benar-benar efektif dalam upaya pemberdayaan koperasi di Jawa Timur.

\section{Metode Penelitian}

Kegiatan sebagaimana dilaporkan adalah gabungan dari kegiatan penyusunan data base, dan analisis data sekunder serta analisis data primer yang diperoleh dari hasil wawancara mendalam dengan para anggota Koperasi yang terlibat sebagai pengurus maupun anggota Koperasi di Jawa Timur. Selain menyusun data base dan melakukan pemetaan terhadap situasi problematik dan isu-isu utama yang timbul dalam upaya pengembangan Koperasi di Jawa Timur, hasil akhir dari kajian yang dilakukan diharapkan berupa program rekomendasi untuk mendorong percepatan pengembangan Koperasi di Jawa Timur yang benar-benar profesional, aplikatif dan efektif.

Untuk memperoleh data yang akurat sebagai dasar penyusunan data base dan pengembangan serta pemberdayaan Koperasi di Jawa Timur, berikut beberapa langkah kegiatan yang telah dilaksanakan. Pertama, melakukan pengumpulan data kondisi perkembangan koperasi dari Dinas Koperasi dan UMKM Provinsi Jawa Timur. Kedua, melakukan analisis data sekunder tentang perkembangan Koperasi di Jawa Timur. Data sekunder terutama dilacak dari berbagai lembaga yang relevan, seperti BPS, Dinas Koperasi dan UMKM, serta Bappeda Provinsi Jawa Timur. Ketiga, melakukan kajian lapangan, yakni langsung mewawancarai para anggota dan pengurus Koperasi di Jawa Timur. Menurut rencana, jumlah responden yang diwawancarai ditetapkan sebanyak 500 responden, yaitu para anggota Koperasi di Jawa Timur.

Lokasi kajian, secara purposive ditetapkan di 5 daerah di Provinsi Jawa Timur, yaitu: Kabupaten Tuban, Kabupaten Jombang, Kabupaten Pamekasan, Kota Kediri, dan Kota Malang. Di masingmasing daerah, telah dipilih 100 anggota koperasi, sehingga secara keseluruhan jumlah responden adalah 500 anggota koperasi (sebagaimana ditunjukkan Tabel 1). 
Tabel 1.

Lokasi Kajian dan Jumlah Responden

\begin{tabular}{cccc}
\hline Kota/Kabupaten & Kecamatan & Kelurahan/Desa & $\begin{array}{c}\text { Jumlah } \\
\text { Responden }\end{array}$ \\
\hline Kabupaten Tuban & Kecamatan Kerek & Kelurahan Margorejo & 50 \\
& Kecamatan Tuban & Kelurahan Karangsari & 50 \\
Kabupaten Jombang & Kecamatan Perak & Kelurahan Perak & 50 \\
& Kecamatan Jombang & Kelurahan & 50 \\
Kabupaten & Kecamatan Tlanakan & Kelurahan Branta & 50 \\
Pamekasan & Kecamatan Proppo & Pesisir & \\
& & Kelurahan Klampar & 50 \\
Kota Kediri & Kecamatan Pesantren & Kelurahan Bareng & 50 \\
& Kecamatan Mojoroto & Kelurahan Bandar & 50 \\
Kota Malang & Kecamatan Klojen & Kelurahan Klojen & 50 \\
& Kecamatan Sukun & Kelurahan Sukun & 50 \\
& Jumlah & 500 & 5 \\
\hline
\end{tabular}

Sumber: Data primer

Dari masing-masing daerah, selain dilakukan survey kepada anggota Koperasi, juga diwawancarai secara mendalam (in depth) sejumlah nara sumber atau informan yang terlibat langsung sebagai pengurus dalam pengelolaan Koperasi, baik Ketua, Bendahara atau Sekretaris), dan staf Dinas Koperasi dan UMKM yang bertanggungjawab dalam pembinaan koperasi karyawan di daerah masingmasing. Wawancara kepada pengurus dilakukan dengan dipandu interview guide yang telah dipersiapkan sebelumnya. Fokus atau ruang lingkup dari kajian yang dilakukan dibatasi pada berbagai persoalan yang berkaitan dengan kinerja, kendala, dan peran Koperasi dalam mendukung pengembangan usaha ekonomi kerakyatan di daerahnya masing-masing. Seluruh data yang berhasil dikumpulkan, telah ditabulasi dan diklasifikasi berdasarkan permasalahan dan tujuan kegiatan yang telah ditetapkan. Sepanjang memungkinkan data ditampilkan dalam bentuk tabel ringkas, dan kemudian akan dianalisis dengan cara dibandingkan dengan studi-studi sebelumnya serta dilakukan interpretasi teoritik atas data yang telah diolah.

Pada bagian akhir kajian ini, dua hal utama yang dikemukakan adalah: (1) problema perkembangan dan peran koperasi di Jawa Timur; dan (2) rumusan program pemberdayaan Koperasi untuk meningkatkan efektivitas dan peran Koperasi di Jawa Timur di masa yang akan datang dalam mendukung peningkatan kesejahteraan anggota serta pengembangan ekonomi kerakyatan di Jawa Timur.

\section{Hasil dan Pembahasan}

Dari hasil kajian yang telah dilakukan, beberapa temuan pokok dari studi ini menunjukkan bahwa proses pembentukan koperasi yang terkadang top down dan kurang memasyarakatnya informasi tentang praktik-praktik berkoperasi yang benar (best practices), acapkali menimbulkan berbagai permasalahan mendasar yang menjadi kendala bagi kemajuan perkoperasian. Sebagian koperasi di 
Jawa Timur terbentuk tanpa didasari adanya kebutuhan atau kepentingan ekonomi bersama dan prinsip kesukarelaan dari para anggotanya, sehingga kehilangan jati dirinya sebagai koperasi sejati yang otonom dan swadaya/mandiri. dalam praktik, ada sebagian koperasi yang masih dijadikan alat oleh kelompok orang untuk kepentingan pribadi yang bertentangan dengan kepentingan anggota koperasi yang bersangkutan dan nilai-nilai luhur, serta prinsip-prinsip koperasi.

Di Provinsi Jawa Timur, jenis koperasi yang berkembang di masyarakat relatif bermacam-macam. Sebagian ada yang berupa koperasi wanita (Kopwan), Koperasi Unit Desa (KUD), koperasi yang banyak didirikan di lingkungan RT/RW, dan koperasi-koperasi lain yang didirikan dengan tujuan untuk membantu para anggotanya yang membutuhkan dana maupun barang keperluan usaha mau pun keperluan hidup sehari-hari. Jenis koperasi yang ada di Jawa Timur, sebagian besar adalah koperasi simpan-pinjam.

Sebagian besar anggota koperasi adalah warga masyarakat yang memiliki tingkat pendidikan yang relatif kurang, sebagian besar secara ekonomi miskin atau paling-tidak termasuk kelompok near poor, dengan kondisi usaha yang relatif stagnan $(63,1 \%)$, atau bahkan cenderung menurun $(23,5 \%)$. Pendapatan yang diperoleh dari usaha yang ditekuni, dalam setahun terakhir umumnya pas-pasan $(51,6 \%)$, dan bahkan kurang $(31,4 \%)$. Permasalahan yang dihadapi masyarakat dalam upaya pengembangan usahanya, sebagian besar karena keuntungan cenderung menurun $(72,8 \%)$, harga jual produk kurang menguntungkan $(46 \%)$, dan jumlah pelanggan juga berkurang $(42,8 \%)$, serta biaya produksi yang naik $(34,6 \%)$.

Selama ini, intensitas anggota koperasi meminjam dana ke koperasi relatif tinggi. Separuh lebih responden $(56,2 \%)$ mengaku telah meminjam ke koperasi dari 6 hingga 10 kali, dan bahkan sebanyak $24,8 \%$ responden mengaku telah meminjam lebih dari 10 kali. Di mata anggota, keuntungan meminjam ke koperasi karena prosedurnya mudah $(47,6 \%)$ dan bunganya lebih rendah (36\%). ratarata jumlah pinjaman anggota ke koperasi tidaklah besar, di mana sebagian besar di bawah 1 juta rupiah. Sebagian besar anggota meminjam ke koperasi sekitar 250-500 ribu rupiah (34,2\%), dan bahkan $22,8 \%$ responden mengaku hanya meminjam kurang dari 250 ribu rupiah.

Sepanjang memungkinkan, responden umumnya lebih memilih meminjam ke kerabat atau saudara yang tanpa membebani mereka dengan kewajiban membayar bunga pinjaman (84,8\%). Alternatif kedua adalah meminjam ke koperasi dengan pertimbangan suku bunga pinjaman relatif rendah dan prosedurnya mudah. Selain itu, menurut sebagian besar responden, meminjam ke koperasi umumnya prosedurnya wajar $(54,6 \%)$, dan bahkan termasuk mudah $(42,4 \%)$, serta sikap pengurus rata-rata adil alias tidak diskriminatif $(63,4 \%)$. Padasaat responden membutuhkan modal untuk usaha, salah satu lembaga alternatif yang seringkali dipilih adalah koperasi (46\%). Koperasi ini menjadi pilihan, terutama ketika responden sudah tidak lagi memungkinkan untuk memperoleh pinjaman yang tanpa bunga dari kerabat atau saudara.

Bagi sebagian angggota koperasi, sepanjang dana atau modal yang dimiliki koperasi mencukupi, mereka sebetulnya mengaku lebih senang meminjam dana ke koperasi karena rata-rata suku bunga pinjaman yang ditetapkan lebih murah daripada lembaga kredit informal lain. Namun demikian, bukan berarti kehadiran koperasi menjadi tumpuan satu-satunya bagi masyarakat ketika mereka membutuhkan pinjaman modal usaha atau dana dalam jumlah tertentu. Studi ini menemukan, selain koperasi, peluang masyarakat untuk mengakses sumber-sumber permodalan lain umumnya masih sangat terbuka. Dari 500 anggota koperasi yang diwawancarai, 37,8\% responden menyatakan mungkin, dan bahkan $20 \%$ responden menyatakan sangat mungkin untuk mengakses sumber-sumber permodalan selain koperasi. Bagi sebagian masyarakat yang terkadang membutuhkan dana yang mendadak, kehadiran rentenir atau bang thithil tetap menjadi salah satu alternatif --terutama jika sudah tidak ada lagi kerabat atau teman yang bisa dimintai bantuan.

Pertimbangan utama responden memilih lembaga perkreditan sebagian besar adalah yang prosedurnya mudah $(33,6 \%)$, waktu pembayaran pinjaman fleksibel $(24,8 \%)$, dan lembaga kredit yang bisa diandalkan untuk memenuhi kebutuhan yang sifatnya mendadak $(24,4 \%)$. Persoalan apakah lokasi 
lembaga kredit tersebut dekat atau jauh, bagi responden tidak menjadi masalah. Demikian juga soal berapa persen bunga pinjaman yang mesti dibayar, tampaknya tidak banyak responden yang mempersoalkan dan menjadikannya sebagai pertimbangan utama dalam memilih lembaga perkreditan yang diakses. Selama ini, keuntungan yang dirasakan sebagian besar responden ketika meminjam ke koperasi adalah prosedurnya mudah $(51,2 \%)$, bunganya rendah $(28,2 \%)$ dan sistem pembayarannya juga fleksibel $(19,6 \%)$.

Meminjam ke koperasi tidak menjadi jaminan bagi kelangsungan usaha yang ditekuni masyarakat. Pasca menerima pinjaman modal atau dana dari koperasi, separuh lebih responden (53\%) menyatakan kondisi usaha yang ditekuni relatif sama. Bahkan, yang memprihatinkan sebanyak $34,2 \%$ responden menyatakan kondisi usahanya justru makin surut pasca menerima bantuan pinjaman modal usaha dari koperasi. Di sini, persoalan yang mereka hadapi bukanlah sekadar pada besar-kecilnya suku bunga pinjaman yang ditetapkan koperasi atau pelepas uang informal yang lain, tetapi yang lebih menentukan kelangsungan usaha mereka berkembang atau tidak adalah kondisi daya beli masyarakat dan iklim persaingan yang makin ketat. Sebeerapa pun rendah suku bunga pinjaman yang diterima responden dari koperasi, tetapi ketika kondisi pasar tengah stagnan, maka yang terjadi kemudian bukan tidak mungkin usaha yang mereka tekuni terancam kolaps.

Ketika masyarakat meminjam ke koperasi, tidak selalu dana yang mereka peroleh dimanfaatkan untuk memenuhi kebutuhan produktif keluarga. Dari 500 anggota koperasi yang diwawancarai, justru sebagian besar $(47,6 \%)$ menyatakan mereka seringkali memanfaatkan dana dari pinjaman koperasi untuk memenuhi kebutuhan non-produktif. Hanya 18,2\% responden yang memanfaatkan pinjaman dari koperasi untuk kegiatan produktif. Sementara itu, sebanyak 34,2\% responden menyatakan jarang memanfaatkan bantuan pinjaman dari koperasi untuk kegiatan konsumtif.

Pinjaman dana yang mereka peroleh dari koperasi umumnya hanya berfungsi sebagai modal tambahan (88\%). Dengan segala keterbatasan jumlah modal yang diputar koperasi, sebagian besar responden mengaku selama ini memang tidak banyak memperoleh pinjaman yang bisa dimanfaatkan untuk modal utama (12\%) dari usaha yang mereka tekuni. Selama ini, jumlah pinjaman yang diperoleh, menurut sebagian besar responden (45,2\%) masih kurang, dan bahkan 31,2\% menyatakan sama sekali tidak mencukupi untuk mendukung pengembangan usaha yang mereka tekuni.

Meski tidak memperoleh pinjaman modal dari koperasi, studi ini menemukan sebagian besar responden $(37,6 \%)$ tetap optimis usaha yang mereka tekuni akan tetap berlanjut, dan bahkan 9,2\% responden menyatakan sangat optimis dan menyatakan sangat optimis usahanya tetap bakal bertahan. Hanya 2,8\% responden yang menyatakan sangat tidak mungkin usahanya bakal dapat bertahan meski tidak memperoleh pinjaman modal dari koperasi. Faktor yang menentukan maju-mundurnya usaha yang mereka tekuni bukanlah akses mereka pada koperasi, melainkan pada kondisi pasar dan iklim persaingan yang disadari responden makin lama makin ketat. Ketika kondisi perekonomian nasional cenderung lesu pasca kenaikan harga BBM, dan kondisi daya beli masyarakat juga menurun, maka peluang untuk mengembangkan usaha apa pun, menurut sebagian besar responden sungguh bukan hal yang mudah.

Dari 500 anggota koperasi yang diteliti, tidak banyak yang optimis terhadap prospek perkembangan usaha yang mereka tekuni. Sebanyak $58,4 \%$ responden menyatakan ragu-ragu terhadap prospek peningkatan omzet usahanya ke depan. Sebanyak 19,6\% menyatakan tidak mungkin, dan bahkan $14,2 \%$ responden menyatakan sangat tidak mungkin usaha yang mereka tekuni dapat ditingkatkan omzet usahanya. Kendala yang menghambat pengembangan usaha anggota koperasi, sebagian besar adalah iklim persaingan yang makin ketat $(51 \%)$, faktor permodalan yang terbatas $(40,2 \%)$, kualitas produk yang dihasilkan $(38,2 \%)$, dan promosi yang kurang $(37,8 \%)$.

Meskipun responden semua adalah anggota koperasi, tetapi bukan berarti mereka dengan leluasa bisa meminjam dan mengajukan pinjaman kapan pun mereka membutuhkan. Sebanyak 38,4\% responden mengaku pernah ditolak ketika mereka mengajukan pinjaman ke koperasi karena berbagai alasan. 
Ketika kondisi keuangan atau modal yang dimiliki koperasi terbatas $(18,7 \%)$, maka peluang sebagian responden untuk memperoleh pinjaman modal dari koperasi relatif kecil. Sebanyak 21,4\% responden mengaku kesempatan mereka meminjam dana dari koperasi memang terbatas dengan alasan untuk pemerataan. Cuma, yang memprihatinkan, sebagian besar responden $(45,3 \%)$ mengaku mereka pernah ditolak meminjam ke koperasi, karena kondisi ekonomi dan pekerjaan mereka tampaknya tidak dipercaya bakal bisa memfasilitasi kewajiban responden membayar cicilan dan pinjaman dari koperasi.

Separuh lebih responden (53\%) mengaku setiap tahun selalu memperoleh pembagian keuntungan atau SHU (Sisa Hasil Usaha). Hanya 25,8\% responden yang menyatakan tidak pernah memperoleh pembagian SHU. Sementara itu, sisanya sebanyak $21,2 \%$ responden menyatakan terkadang mereka menerima pembagian SHU --cuma sifatnya tidak rutin. Kalau dicoba dikuantifikasi, pembagian SHU yang diterima responden, rata-rata tidak banyak. Sebagian besar hanya menerima SHU sekitar 50-100 ribu, dan paling banyak tidak lebih dari 200 ribu. Hanya 23,7\% responden yang mengaku menerima SHU sekitar 150-200 ribu. Studi ini menemukan, sebanyak 41,5\% responden menerima SHU dalam bentuk sembako atau peralatan rumah tangga, seperti panci, wajan, tempat minum, dan lain sebagainya. Bagi anggota koperasi yang tidak menerima SHU, alasan yang dikemukakan pengurus koperasi biasanya karena lembaga mereka kekurangan modal untuk mengembangkan usaha $(59,7 \%)$, dananya habis untuk perputaran modal $(20,9 \%)$, atau koperasi tidak memiliki saldo keuntungan yang bisa dibagikan kepada anggotanya $(19,4 \%)$.

Dibandingkan lembaga kredit informal, kelebihan koperasi menurut responden umumnya adalah dalam hal ancaman sanksi $(68,2 \%)$ yang lebih ringan atau fleksibel, persyaratan agunan (60\%) yang tidak terlalu membebani atau bahkan tidak dipersyaratkan, dan kecepatan pencairan pinjaman yang lebih baik (56,2\%). Selain itu, cukup banyak responden yang juga menyatakan bahwa dibandingkan lembaga kredit informal, seperti rentenir, atau pelepas uang informal lain, koperasi memiliki keunggulan dalam persoalan besar bunga pinjaman yang ditanggung responden (37,8\%), birokrasi pengurusan yang lebih mudah $(35,4 \%)$, dan ketentuan pembayaran cicilan yang lebih fleksibel $(34,2 \%)$.

Jumlah anggota koperasi di berbagai lokasi penelitian sebagian besar diketahui meningkat. Sebanyak 358 responden menyatakan jumlah anggota koperasi meningkat, dan hanya 37 responden yang menyatakan jumlah anggota koperasi menurun. Sementara itu, sebanyak 105 responden menyatakan jumlah anggota koperasi relatif tetap. Sebagian koperasi diketahui telah makin besar dan memiliki tambahan anggota baru hingga menjadi $26-50$ orang $(31,6 \%)$. Sementara itu, sebagian koperasi lain diketahui telah menambah jumlah anggota hingga lebih dari 50 orang (12\%). Namun demikian, tidak selalu semua koperasi bertambah jumlah anggotanya. Sebagian kperasi diketahui jumlah anggotanya justru makin menurun $(7,4 \%)$, dan sebagian yang lain (28\%), jumlah anggotanya tetap.

Jumlah anggota koperasi cenderung bertambah banyak, sebagian besar karena memang para anggota baru itu umumnya membutuhkan pinjaman dari koperasi $(44,1 \%)$, dan sebanyak $39,1 \%$ responden menyatakan anggota koperasi mereka bertambah banyak karena prosedur untuk menjadi anggota koperasi relatif mudah. Sebanyak $16,8 \%$ responden menyatakan anggota yang bertambah dan tertarik menjadi anggota baru koperasi karena adanya sistem tanggung renteng. Sementara itu, faktor penyebab anggota koperasi berkurang sebagian besar $(75,7 \%)$ karena banyak anggota yang tidak melunasi pinjaman atau utangnya pada koperasi, hingga kemudian mereka keluar dari anggota kop7erasi yang bersangkutan. Sebanyak $24,3 \%$ responden menyatakan anggotanya berkurang karena mereka memilih pinjam ke lembaga perkreditan lain.

\section{Simpulan}

Jenis koperasi yang berkembang di masyarakat relatif bermacam-macam. Sebagian ada yang berupa koperasi wanita (Kopwan), Koperasi Unit Desa (KUD), koperasi yang banyak didirikan di lingkungan RT/RW, dan koperasi-koperasi lain yang didirikan dengan tujuan untuk membantu para anggotanya yang membutuhkan dana maupun barang keperluan usaha mau pun keperluan hidup sehari-hari. Jenis 
koperasi yang ada di Jawa Timur, sebagian besar adalah koperasi simpan-pinjam. Sebagian besar anggota koperasi adalah warga masyarakat yang memiliki tingkat pendidikan yang relatif kurang, sebagian besar secara ekonomi miskin atau paling-tidak termasuk kelompok near poor, dengan kondisi usaha yang relatif stagnan, atau bahkan cenderung menurun. Pendapatan yang diperoleh dari usaha yang ditekuni, dalam setahun terakhir umumnya pas-pasan, dan bahkan kurang. Permasalahan yang dihadapi masyarakat dalam upaya pengembangan usahanya, sebagian besar karena keuntungan cenderung menurun, harga jual produk kurang menguntungkan, dan jumlah pelanggan juga berkurang, serta biaya produksi yang naik.

Kedepan, meski ada yang bersikap pesimistis terhadap masa depan perkembangan koperasi, akan tetapi prospek perkembangan koperasi diyakini sebagian besar responden akan makin besar, sebab banyak warga masyarakat yang membutuhkan koperasi untuk tempat meminjam modal usaha mau pun untuk memenuhi kebutuhan hidup sehai-hari.

\section{Daftar Pustaka}

Agustia D \& Palupi A (2016) Praktik Creative Accounting pada Koperasi di Jawa Timur. Ekuitas: Jurnal Ekonomi Dan Keuangan 20(4):522-543.

Anoraga P \& Sudantoko D (2002) Koperasi Kewirausahaan dan Usaha Kecil. Semarang: Rineka Cipta.

Arifandy, Norsain \& Imam DF (2018) Peran Koperasi dalam Meningkatkan Perekonomian Masyarakat Nelayan: Perspektif Modal Kerja. Jurnal Akademi Akuntansi 3(1):118-132.

Heriyono (2012) Peran Koperasi Dalam Pengembangan Perekonomian Rakyat. Fakultas Ekonomi Universitas Tujuh Belas Agustus Cirebon.

Ilhamidya DN, Sri K \& Titin K (2020) Analisis Efisiensi Penggunaan Modal Kerja Pada Koperasi Karyawan Sekar Jember Tahun Buku 2015-2017. Jurnal Pendidikan Ekonomi: Jurnal Ilmiah Ilmu Pendidikan, Ilmu Ekonomi dan Ilmu Sosial 14(1):213-217.

Melani, Winny R, dkk (2013) Peran Koperasi Dalam Meningkatkan Perokonomian Masyarakat Nelayan.

Sulindawati LGE (2012) Penyusunan Laporan Arus Kas Untuk Koperasi. Media Komunikasi FPIPS, 11(1):1-15.

Syamsuri (2020) Strategi Pengembangan Ekonomi Berdikari di Pesantren Gontor Berbasis Pengelolaan Kopontren. Al-Intaj 6(1).]

Warno \& Setiyanti SW (2014) Konsistensi Penerapan SAK Syariah pada Koperasi Syariah. Jurnal STIE Semarang 6(2):50-63.

Yuniarta (2020) Kebutuhan Tenaga Profesional Pada Koperasi Di Kabupaten Buleleng. Media Komunikasi FPIPS 19(1): 52-61. 